\title{
Prospects of Sustainability of Thomas langur (Presbytis Thomasi) Based on Group Size in Pinus Jantho Natural Reserve, Aceh Besar, Aceh Province
}

\author{
Ruskhanidar $^{1,6^{*}}$ Hadi S. Alikodra ${ }^{2}$ Entang Iskandar ${ }^{3} \quad$ Nyoto Santoso $^{4} \quad$ Sri Supraptini Mansjoer $^{5}$ \\ 1,3,5. Program of Primatology, Bogor Agricultural University Jl. Lodaya II No. 5 Bogor 16151, West Java, \\ Indonesia \\ 2,4. Department of Forest Resources Conservation and Ecoturism, Faculty of Forestry, IPB, Darmaga, Bogor \\ 16680, West Java, Indonesia \\ 6. Sekolah Tinggi Ilmu Kehutanan Pante Kulu (STIK Pante Kulu) Jl. Tgk, Daud Beureueh Darussalam Banda \\ Aceh, Indonesia
}

\begin{abstract}
Thomas langur (Presbytis thomasi) is endemic Sumatran primates. Its distribution is limited in Aceh and small areas of North Sumatra. The population of this species is very threatened because its habitats has been disturbed, especially by forest fires. This study aimed to determine the sustainability of the thomas langur in Pinus Jantho Nature Reserve (PJNR). Observations were conducted from December 2017 to September 2018 in rehabilitation and protection block, with an area of 184 ha of research sites. The research method used the strip transect sampling and questionnaire. The numbers of observation transects are 23 strips which differ strip lengths. The results shows that there are several various sizes of thomas langur groups. The seven groups consists of from two to seven individuals per group, with a composition of six groups of one male multi female group and all male groups. The total population size with 34 individuals consists of eight adult males, nine adult females, 12 subadult and five infant. The age structure is categorized as stable age structure that evidenced by the age of young Thomas langur, the total numbers of infant and subadult, the same as adult thomas. The sex ratios of adult thomas langur is $1: 1,12$, and young ages including infant and subadult, with adults 1:1. The sustainability prospect based on indicators of group size and population size does not continue in the PJNR, however it can develop naturally in the PJNR because it has a group composition
\end{abstract}

Keywords: Presbytis thomasi, Population, Nature Reserve.

DOI: $10.7176 / \mathrm{JNSR} / 12-8-04$

Publication date: April $30^{\text {th }} 2021$

\section{Introduction}

Thomas langur in the local name is kedih (Presbytis thomasi) is one of Indonesia's non-human primate species, endemic to northern Sumatra, namely Aceh and Langkat, North Sumatra Province. Its life is highly dependent on primary and secondary forests, within conservation areas and other forest areas. The Thomas langur was found at the Ketambe Research Station (Sterck, 1995; Steenbeek, 1999; Wich, 2002; Wich 2010), in Soraya Research Station and Sikundur (Syaukani, 2013), in Sikundur (Zannah, 2017; Slater, 2015), the National Park area Gunung Leuser, South Aceh in the Leuser ecosystem area (Faridha, 2014), Jantho Aceh Besar (Supriatna \& Hendras, 2000) and North Sumatra include Langkat, Wampu River (Gurmaya, 1986) Togar Marganda (Iman, 2017). It is estimated that the thomas langur populations continues to decrease. In 1986, 184 individuals were found at the Ketambe Research Station (Gurmaya, 1986) and 56 individuals were found at the Soraya Research Station in 2012 (Syaukani, 2012). This decline occurred because of habitat diversion, forest fires, and ilegal hunting. Forest fires are a problem that cannot be overcome in the Pinus Jantho Nature Reserve (NRPJ). NRPJ is a conservation area designated as a nature reserve for endemic of Aceh Pine and an important habitat for a number of macrofauna and primate animals. Designated as a conservation area based on Forestry Minister Decree No. 186 (1984) with an area of 16,640 ha. However, based on the latest evaluation of the status of the Nature Reserve, the area has been reduced to 15,356.49 ha, in accordance with SK KLHK No.101 (2015) concerning the area of the Pinus Jantho Nature Reserve. Based on the records form 1980 to 2000, roughly 20\% of the total forest canopy cover has been opened in the Pinus Jantho Nature Reserve especially wood species that have the potential to have high economic value (Ilhartuti, 2014). This condition would result in the loss of feed and sleeping trees and their playground. This situation can restrict thomas langur to get a food source. The limited number of feed trees results in the adequacy of nutrients needed by thomas langur. According to Lomolino et al. (2010) habitat can determine the successes and deficiencies of a population. This condition, if it continues, can lead to extinction on a local scale. Another pressure is the existence of people whose lives are highly dependent on land and forest resources either in the forest of conservation area or non-conservation area (Kadir et al. 2012). There are 4 gampong (villages) bordering with NRPJ area, in which people have works traditionally in farming and gardening. To sustain their lives, they cut down trees in the forest, cultivate forest 
land, and herd cattle in forest areas (Mitchel et al. 2016). Thomas langur is one of the primates that has been protected by law based on Minister of Environment and Forestry Regulation No: P.20.MENLHK/SETJEN/KUM.1/6/2018, Minister of Forestry Decree No.301/Kpts-II/1991 concerning the Inventory of Protected Animal by the Law, in Act No. 5 of 1990 concerning Conservation of Biological Resources and Ecosystems (Supriatna et al. 2000). Its conservation status is listed as vulnerable in the list of IUCN (International Union for the Conservation of Nature and Natural Resources) and Appendix II in CITES (Convention on International Trade in Endangered Species of Wild Fauna and Flora). The size of the kedih population is one indicator to assess the prospects for sustainability of the Thomas langur. Conserving kedih must be increased, before its status is upgraded to become extinct on a local scale and its existence will sustain in the future. To find out the prospect of continuous sustainability, it is needed NRPJ research in the NRPJ. This research is important to carry out because only a few research was carried out on the grime in its natural habitat, and there has been no research on the species in the NRPJ.

\section{Materials and Methods}

\subsection{Study area}

The study was conducted from December 2017 to September 2018, at NRPJ, Aceh Besar District, Aceh Province. Study area, geographically, is located at $05^{\circ} 13^{\prime} 08$ North Latitude, $95^{\circ} 40^{\prime} 54$ east longitude. Observations were conducted in the protection block and rehabilitation block which starting from 6.00 AM to 06.00 PM of West Indonesian Time. Total observations were 1,300 hours

\subsection{Equipment}

The equipment used consist of: 1) map; 2) Garmin Global Positioning System (GPS) map 76 C 5x to record coordinates when kedih is identified; 3) Binoculars Nicon Action Ex 8x40 YLTI Rp. Rc Binoculars to clarify images; 4) compass as directions; 5) Nicon Coolpix P 900 camera for documentation, 8) stationery. plastic bags, as a place for collecting leaves, fruit and feed seeds for unidentified species. $70 \%$ alcohol as a preservative, especially for plant species that are not known by local names. Samples of leaves, fruit and seeds were analyzed at the Biology Herbarium Laboratory of Syiah Kuala University. The research location is presented in Figure 1

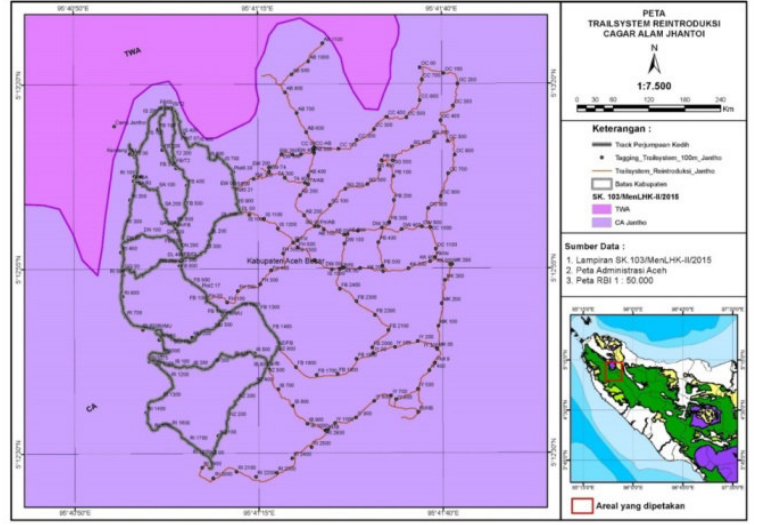

Figure 1. Map of research locations in Pinus Jantho Nature Reserve.

\subsection{Data collections}

Primary and secondary data were collected for analyzing the prospect of sustainability of thomas langur. Primary data were collected through field surveys and interviews through forms that have been prepared for the communities around the CAPJ, the CAPJ managers, and other stakeholders. Secondary data was obtained from various sources such as dissertation, thesis, BPS, BMKG, BKSDA, and other reports related to the research topic. The steps involved in collecting data are: (1) Identifying indicators of sustainable nature reserves based on literature studies and field observations. (2). Inventory and analyze conditions of thomas langur population in CAPJ. The aspects of the thomas langur population include group size, sex ratio, individual size, and age structure of kedih. To find out the thomas langur population in the CAPJ was used the line transect sampling method. Line transect sampling was used to trace the thomas langur groups. The line transect is set in the home range of thomas langur. To avoid double counting, groups are determined based on a distance of $200 \mathrm{~m}$ (Kyes et al. 2016). There are 23 line transects were made with different lengths following the topographical conditions, and the width of the lanes was $50 \mathrm{~m}$ left and right, respectively, includes two rehabilitation and protection blocks The total area of the transect line for the two blocks is 184 ha.

In the observation of thomas langur (P.thomasi) observation, the total number of group members, gender, and age class of each individual in the group were recorded based on the results of identification. Each group was distinguished by the criteria of male adult, female adult, juvenile and infant. The group composition data 
that have been obtained are presented in tables and graphs, so that the composition of each group can be known.

\subsection{Data analysis}

- Thomas langur compotition

In the observation of thomas langur (P.thomasi) observation, the total number of group members, gender, and age class of each individual in the group were recorded based on the results of identification. Each group was distinguished by the criteria of male adult, female adult, juvenile and infant. The group composition data that have been obtained are presented in tables and graphs, so that the composition of each group can be known.

- Population density of Thomas langur

Group composition data that have been obtained are presented in tabular form, so that the compositionof each group can be known. To find out the population density of P.thomasi can be done using a formula: $\mathrm{P}=\mathrm{D} \times \mathrm{A}$ :

$\mathrm{D}=\frac{\Sigma_{\mathrm{n}}}{\mathrm{A}}$

Nore: D is population density, and A is the area of survey area while $\mathrm{n}$ is the number of Thomas langur individuals.

- Prospect of Sustainability of Thomas langur

The prospect of sustainability is carried out using the amoeba diagram approach through several stages, including the determination of indicators consisting of populations, and the habitat of the bladder and the communities around the NRPJ. For each indicator in each parameter a score is given that reflects the conditions of sustainability. The range of scores is determined based on criteria that can be found from observations. The range of scores ranges from 1-9, depending on the state of each indicator interpreted starting from low, medium and high. Low scores reflect the most unfavorable conditions for the prospect of sustainability, whereas good values reflect the most favorable conditions. Table 1 presents the indicators and scores that will be used to assess the condition of the prospects for sustainability in the NRPJ. The value of each indicator is analyzed by using the Amoeba diagram to determine the position of the prospect of sustainability in the NRPJ. The results of the analysis are presented in the form of drawings and diagrams.

Table 1. Indicators population of sustainability prospects of Thomas langur

\begin{tabular}{|l|l|l|}
\hline Indictors & Scores & Category \\
\hline Group size & 3 & Low \\
\hline Individual size & 3 & Low \\
\hline Sex group & 3 & Low \\
\hline Age group & 3 & Low \\
\hline
\end{tabular}

Note : 1-3: low; 4-6 : intermediate; and 7-9 : high.

\section{Result and Discution}

\subsection{Population size}

A population size can be expressed as the number of individuals found in a group. Population sizes that were identified at the study site in rehabilitation block were two individuals and in protection block were varies from four to seven individuals. In the rehabilitation block, the group size with two individuals $(28.57 \%)$ was two groups. The smallest group in protection block here were four individual (14.28\%) in a group, five individual $(14.28 \%)$ in a group, and the largest was seven individual $(42.85 \%)$ as three groups. The size of kedih groups found in study of Steenbeek (1999), and Sterck (1995) that ranged from 4-10 individuals and Gurmaya (1986) 421 individuals at the Ketambe Research Station and 5-12 individuals found by Syaukani (2012) at the Soraya Station Research, Gunung Leuser National Park. The group size of Thomas langur is smaller than the simpai (Presbytis melalophos) group that studied by Violita et al. (2015) totaling 11 individuals per group in the forest of Cugung village, South Lampung and four surili (Presbytis comata) found by Widiana et al. (2018) in the Ciharus Kamojang block in Garut Regency, and 12 Javanese langurs per group (Giovanna 2015)

There are differences in group size between the thomas langur in Ketambe and Soraya and the thomas langur in the NRPJ, due to the time and location of observations and different habitat types. Many factors affect the size of the size of the kedih population. Referring to the 1984 Bailey population size is influenced by the age of early maturity, and Alikodra (1990) states that the size of the animal group is affected by birth rates, mortality rates, emigration and immigration. Of the 34 individual, the composition consists of eight individuals $(23.53 \%)$ are adult males, nine individual $(26.47 \%)$ are adult females, 12 individual $(35.29 \%)$ are juveniles and five individuals are (14.71\%) infant. The Thomas langur groups were identified in the NRPJ 30 individuals are (14.71\%) infant. The kedih groups were identified in the NRPJ 30 individuals in the protection block and four individual in the rehabilitation block are presented in Table 2 
Table 2. Composition and size of kedih groups in the protection and rehabilitation blocks in the NRPJ

\begin{tabular}{|l|l|l|l|l|l|l|l|}
\hline Block & Lines & Total group & AM & AF & SA & I & Total \\
\hline Rehabilitation & IS 300 & 1 & 2 & - & - & - & 2 \\
\hline & SA & 1 & 1 & 1 & - & - & 2 \\
\hline Total & & 2 & 3 & 1 & & & 4 \\
\hline Percentage (\%) & & & 75 & 25 & & & 100 \\
\hline Protection & RI 1100 & 1 & 1 & 1 & 1 & 1 & 4 \\
\hline & FB 650 & 1 & 1 & 2 & 3 & 1 & 7 \\
\hline & IS 1000 & 1 & 1 & 2 & 3 & 1 & 7 \\
\hline & GG & 1 & 1 & 1 & 2 & 1 & 5 \\
\hline & DN & 1 & 1 & 2 & 3 & 1 & 7 \\
\hline Total & & 5 & 5 & 8 & 12 & 5 & 30 \\
\hline Percentage (\%) & & & 16,67 & 26,66 & 40 & 16,67 & 100 \\
\hline
\end{tabular}

The six groups were identified as the Thomas langur group as one male multi female group, and a group with all males. In NRPJ, there are no solitary males were found, as recorded by Sterck (1995) and Wich (2002) of thomas langur population in the Ketambe Research Station. The age distribution in Table 2 showed that adolescent Thomas langur was higher than male and female adults and infant. This is a potential for future breeding of Thomas langur that can occur in the NRPJ. Moreover, there were no subadult and infant found in the rehabilitation block, it is suspected that in this block new adult males and females joined to a form group, so that they did not have infant yet.

\subsection{Thomas langur density}

Group density is expressed as the number of groups in a area. The density of the Thomas langur group in the rehabilitation block is 0.71 group $/ \mathrm{km}^{2}$ and 0.19 group $/ \mathrm{km}^{2}$ in the protection block. Furthermore, the individual density is 1.42 individuals $/ \mathrm{km}^{2}$ in the rehabilitation block and 1.14 individuals $/ \mathrm{km}^{2}$ in the protection block. The density of this group is lower than the found by Anwar et al (1984), namely 2 groups $/ \mathrm{km}^{2}$, Gurmaya (1986), Sterck (1995) and Wich at al. (2010) in the secondary forest of the Ketambe Research Station which found 2.7 animals $/ \mathrm{km}^{2}$ and 3.5 animals $/ \mathrm{km}^{2}$ in the primary forest. However, this density is still higher than the 0.08 individual/ ha Lutung density studied by Astriani et al. 2015 at the Balanan Baluran National Park resort, 0.62 individuals/ha Javan langur in the Ololanang Kecubung Nature Reserve, Batang, Central Java District Rahmawati \& Hidayat 2017). Even though the rehabilitation block dominated by a secondary forest type, it uses it as a preferred place to find food, and uses it as a pathway. In accordance with the findings of Bismark (2012) and Gurmaya (1986) where primates have a higher frequency of time use in open spaces.

\subsection{Sustainability Prospects of Thomas langur In NRPJ}

The prospect of sustainability of Thomas langur in the NRPJ can be analyzed from indicators of population, habitat, and the communities around the NRPJ area. These indicators are presented in Table 3.

Table 3. Indicators and values for sustainability in the CAPJ

\begin{tabular}{|l|l|l|l|}
\hline Indicators & Scores & \multicolumn{3}{|l|}{} \\
\hline Population & NRPJ & Ketambe & Soraya \\
\hline Group size $\left(\mathrm{km}^{2}\right)$ & 7 & 9 & 6 \\
\hline Individual size $\left(\mathrm{km}^{2}\right)$ & 34 & 87 & 49 \\
\hline Sex ratio $(\%)$ & $1: 1$ & $1: 3$ & $1: 3$ \\
\hline
\end{tabular}

Table 3 shows the values of the indicators analyzed using the Amoeba diagram (Bell et al. 2003). Amouba diagram is a device to show the balance format of all indicators on the line. The results of the analysis of the three indicators are presented in the form of Figure 2

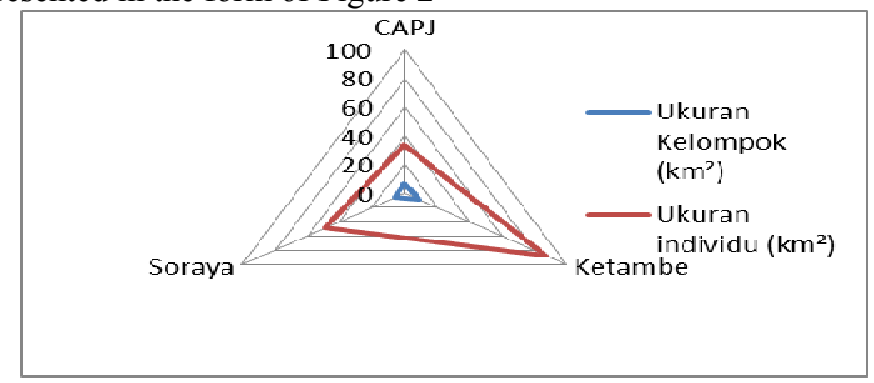

Figure 2. Kite diagram of population size, and the size of bladder groups in three different locations in onservation areas in Aceh

The results that show in the Figure 2 explain the number of boiling groups is lower than Ketambe, but still 
higher than the boiling in Soraya. Based on the size of the Thomas langur population in the NRPJ are in the category of less sustainable or in the low category. Although the results show less sustainable, the Thomas langur population in NRPJ can still grow and develop in the future because it has a complex group composition, with the number of adult females slightly more than adult males. The prospect of continuous sustainability in NRPJ can still occur naturally by letting Thomas langur develop naturally and through human intervention by engineering with restocking of adult female kedih from outside of NRPJ area.

\subsection{Prospect of Thomas langur population Sustainability}

The results that show in the Figure 2 explain the number of boiling groups is lower than Ketambe, but still higher than the boiling in Soraya. Based on the size of the Thomas langur population in the NRPJ are in the category of less sustainable or in the low category. Although the results show less sustainable, the Thomas langur population in NRPJ can still grow and develop in the future because it has a complex group composition, with the number of adult females slightly more than adult males. The prospect of continuous sustainability in NRPJ can still occur naturally by letting Thomas langur develop naturally and through human intervention by engineering with restocking of adult female kedih from outside of NRPJ area.

- Natural sustainability of Thomas langgur

Naturally, the sustainability of Thomas langur can continue and the population can still increase due to having productive adult females and adult males who can mate at any time, as well as the presence of adolescent potential for reproduction. Sustainability is affected by group size, age structure and sex ratio.

- Group Size of Thomas langur

Based on the results of the analysis of the condition of the Thomas langur population in the NRPJ, it can be seen that currently there are seven groups with size from two until seven individual a group. The size of kedih in the NRPJ is in the low category referring to Anwar et al. 1984, which found 10 individuals/a group in the Sumatran lowland forest, and 1986 Gurmaya who found a group size of 4 to 20 individuals/a group, while Sterck (1995) found that a group size of 4 to 10 individuals per group in the Gunung Leuser National Parks and Syaukani (2012) found a group size of 5 to 12 individuals at the Soraya Research Station.

Group densities per hectare, in the NRPJ also included in the low category refers to Anwar et al 1984 who found 29 individuals $/ \mathrm{km}^{2}$ and group density of 2.9 groups / $\mathrm{Km}^{2}$ and Gurmaya (1986) found two groups of kedih per $\mathrm{km}^{2}$. The highest group size in the protection block and rehabilitation block is the smallest group size. The largest group size in NRPJ is different from Gurmaya (1986) who found the largest group size in the Bukit Lawang secondary forest and the smallest in the primary forest of the Ketambe Research Station in Gunung Leuser National Park, and Sampurna et al. (2014); Lindburg (1980) found the largest size of the Macaca fascicularis group in disturbed forests and found on plantation land and Bismark (2012) found P.potenziani to use $54 \%$ of its time in primary forests, S.concolor uses $50 \%$ of its time in forests primary.

The size of the group according to Bayle (1984) influenced by factors of birth, motality, emigration, and immigration as well as the ability to deal with other groups and how to deal with group formation. The size of the boiling group in the NRPJ can still be increased to a larger size in the future because each group has infan

- Age structures

The most important characteristic in analyzing population dynamics and can be used to assess the success of Thomas langur breeding in the NRPJ is by using the value of age structures. The age group follows the Sterck (1995) namely infant, subadult, adult females and adult males. Important characteristics of the population that can describe the status of ongoing reproduction can be seen from the age distribution. The age groups identified in the protection and rehabilitation blocks are presented in Table 4.

Table 4. Structures of age in NRPJ

\begin{tabular}{|l|l|l|l|l|}
\hline Group age & Protection Block & Total (\%) & Rehabilitation Block & Total (\%) \\
\hline Infant & 5 & 16,67 & - & \\
\hline Subadult & 12 & 40,00 & - & \\
\hline Adult & 13 & 43,33 & 4 & 100 \\
\hline Total & 30 & 100 & 4 & 100 \\
\hline
\end{tabular}

The age range in Table 4 shows that the number of subadult is higher in the protection block, indicating that the reproductive ability is quite good in the protection block. The rehabilitation block is not found in infant and subadult, this indicates that there is no reproduction in this block. The absence of reproduction is suspected because female individuals and new adult males have joined in forming a new group. Based on the age distribution of Thomas langur in protection block can develop in the future, but in the rehabilitation block the opportunity to develop is very small because there are only one adult female existed.

In the rehabilitation block, the large number of males has the opportunity to increase the scale of a fight in getting females. The age structure of the population as a whole shows that the condition of the developing population is characterized by a higher number of infant and subadult or young people (56.47\%) compared to the 
number of adult classes (43.33\%) which is expected to be quite productive in the protection block. In the rehabilitation block, the population structure has declined, due to the absence of new births. There is only one age group in the rehabilitation block, namely the adult age group only with an adult female. The age range in the protection block indicates that kedih in the NRPJ in the future can still develop, because the age range for youth is in greater numbers.

Age structure can be used to assess the prospects of the development of a population's sustainability, so that it can be estimated or assessed the success of a wildlife development. The age structure of the NRPJ consists of adult males, adult females, subadult and infant. The results of the analysis show that young age is higher than adult females. The high young age group illustrates the grief in NRPJ has the potential to continue. The age structure in the NRPJ consists of infant, subadult and adults. From the analysis results obtained age structure of $35 \%$ subadult, $25 \%$ each for females and adult males, $15 \%$ of infant. The structure of the urinary age is presented in Figure 3

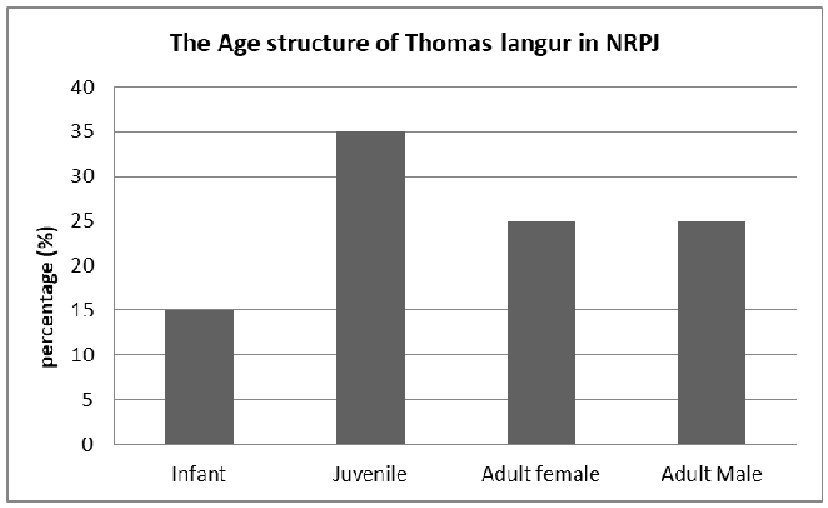

Figur 3. Age Structure in NRPJ.

\section{- Sex ratio}

Sex ratio is a comparison between the number of male individuals and the number of females (Alikodra 1990). Sex ratio is usually expressed as the number of males in 100 females. Calculation of sex ratio can be classified into general sex ratio and reproductive sex ratio. The sex ratio in this study was calculated as a whole of 1: 1.6 between male and female adults. The sex ration of adult female is slightly higher than adult male, between young and adult is 1: 1.3 , in the rehabilitation block is 1:0.3. Female is smaller number than male. Sex ratio in this study was not counted in the age group of infant. From the comparison of the sex ratio it can be seen the productivity of infant born to each adult female giving birth to one child in each group. Productivity can be obtained by dividing the number of infant by adult female parent multiply by $100 \%$. From this division, it can be seen that each adult female parent can give birth to two infant in each group. The sex comparison explains that reproduction in the future can still occur, specially in the protection block. It can be seen from the presence of infant in each group. Referring the number of individuals and the composition of the sex ratio, Thomas langur naturally can still able to reproduce in the protection block of CAPJ. The successful reproductive is highly dependent on the age of sexual maturity of an individual (Bailey 1984).

Thomas langur has a long life span in its natural habitat up to \pm 20 years (Supriatna et al. 2000) and according to Witch et al. (2010) the female life span in its natural habitat reaches 21 years and the maturity age of sex in females is 4.5 years (Supriatna et al. 2000) and five years in males (Which et al. 2007, Steenbeek 1999). The infant is nursed during 26 months, and 17.7 months if the baby dies (Which et al. 2007). Based on the information and the results of the 2018 study, it is concluded that Thomas langur population in the NRPJ both in the protection and rehabilitation block can still develop. Referring to Bailey (1984) the amount of annual reproduction of wild animals is determined by the time the breed begins, the number of adult sex individuals per year, adult sex size, infant survival, parent care, oldest age of mating. By considering the first sexual maturity and nursing period, female adult can give birth every 2.5 years. Throughout its life, female can give birth as four to five infant in the NRPJ with a number of productive females nine individuals throughout the and it can increase the population of 36-45 individuals

Sex ratios as one indicator in the prospect of sustainability of Thomas langur in the NRPJ. Sex ratio can be divided into general sex ratio and productive sex ratio. In this study, the sex ratio is $1: 2,3: 1,6$. By referring the ratio, there are 1:1 ratio between adult male and adult female individuals and from the age structure of infant and adult females the ratio is 1: 2 . The population of Thomas langur in NRPJ can still grow to reach the same amount in the Ketambe Research Station, although it takes a long time. It is estimated that to increase the population by as much as kedih in the Ketambe Research Station takes 12 years. This time prediction is based on the early age of sexual mature of female is 4.5 years, the interval between births is 27 months, and the pregnancy period is 6 months. There are currently 9 adult females and 8 adult males existed and 12 teenagers and 5 infant. Sex ratio 
ratio $1: 1.13$. This amount can be achieved if the habitat conditions are conducive, there are no deaths during this period, and each female can give birth to one child. Predictions of increasing population in the NRPJ are presented in Table 5 below.

Table 5. Prediction of additional population by natural process

\begin{tabular}{|l|l|l|l|l|l|l|}
\hline Years & AM & AF & SAM & SAF & I & Number \\
\hline Current (2020) & 8 & 9 & 12 & & 5 & 34 \\
\hline 4 year I (2024) & 14 & 15 & 2 & 3 & 15 & 49 \\
\hline 4 year II (2028) & 16 & 18 & 7 & 8 & 18 & 67 \\
\hline 4 year III(2032) & 23 & 26 & 9 & 9 & 26 & 93 \\
\hline
\end{tabular}

Remarck : AM: adult male, AF: adult female, SAM: subadult male, SAF: Subadul female, I: infant

- Kedih Sustainability by Restocking Engineering

The acceleration process to increase the Thomas langur population in NRPJ equal with population in the Ketambe Research Station for continuing the sustainability prospect in the NRPJ can be carried out through the introduction of adult female to the NRPJ. Females adult as stockings can be obtained by capturing wild Thomas langur from the Gunung Leuser National Park or from the Leuser Ecosystem, due to the absence from captivity. Introduction by supplying with 15 new adult females, with a ratio of 1: 3 referring to the size of the kedih group at the Ketambe Research Station, there are 1 adult male with 3 adult females in agroup. The number addition is 15 adult females, because currently 8 adult males have been existed in the NRPJ.

The addition of adult female in the kedih groups refers to Wich et al. 2010 that there is no competition in the social life of females in the kedih group and the chance of female life is greater than males. Adult females can also choose new males for their life partners according to Sterc 1995 and Wich et al. 2010. The kedih population can develop faster with the restocking engineering with new adult females compared to the growth in the natural population. With the addition of adult females to the NRPJ, in the 8 year, Thomas langur population can reach in the same amount in kedih population of the Ketambe Research Station. Briefly, it requires less period time than natural process. Predictions of sustainability in the NRPJ with the addition of new female individuals are showed in Table 6.

Table 6. Engineering population by restocking with 15 individuals of female adult

\begin{tabular}{|l|l|l|l|l|l|l|}
\hline Years & AM & AF & SAF & SAM & I & Number \\
\hline Initial restocking & 8 & 9 & 12 & & 5 & 34 \\
& 8 & 15 & 12 & & 5 & 40 \\
\hline 4 year I & 14 & 21 & 2 & 3 & 21 & 61 \\
\hline 4 year II & 16 & 24 & 10 & 11 & 24 & 97 \\
\hline 4 year III & 26 & 35 & 12 & 12 & 35 & 120 \\
\hline 4 year IV & 38 & 47 & 12 & 13 & 47 & 157 \\
\hline
\end{tabular}

Remarck : Note: AM: adult male, AF: adult female, SAM: subadult male, SAF: Subadul female, I: infant

\section{Conclusion}

The Thomas langur population in the NRPJ may develop in the future, especially in the protection block even though the number of groups, group size, and number of individuals is low, but has a complex group composition, with the number of adult females slightly higher than adult males, and a higher number of juveniles than adults. The age structure and sex ratio in the protection block allows Thomas langur to breed well, while Thomas langur population in the rehabilitation block does not show the ideal age and sex ratio structure. The prospect of sustainability in the NRPJ, from population indicators, is not sustainable. Therefore, it is necessary to take appropriate action in the management of Thomas langur in the future, however Thomas langur population can increase in the future through restocking efforts. Thomas langur population is quite a complex composition with the age structure of the adult female higher than adult male and subadult higher than adult female

\section{References}

Alikodra, H.S. (2019), "Ecology Conservation Wildlife Management”, IPB University. Bogor. Indonesia.

Astriani, W.I., Arief, H., \& Prasetyo, L.B. (2015), "Population and habitat of lutung jawa (Trcyphitecus auratus

E. Geoffrey 1812) in Balanan Resort, Baluran National Park”. Jurnal Media Konservasi. 20 (3), 226-234

Anwar, J., S.J Damanik., N. Hisyam., \& A.J Whitten. (1984), “Ecology of Sumatra Ecosystem”, Gajah Mada University press. Yogyakarta.

BKSDA Aceh. (2018), "Forest and Land Fire”, Report of Cagar Alam Hutan Pinus Alami Jantho.

Bismark, M. (2012), "Conservation model of endemic primate in Pulau Siberut Biosphere Reserve, Sumatera Barat", Jurnal Penelitian Hutan dan Konservasi Alam. 9(2), 151-162

Bayle, J..A. (1984), "Principle of Wildlife Management". Colorado State University

Faridha, N. (2014), "Habitat description of Kedih (Presbytis thomasi) in Panton Luas natural forest, Sama Dua 
District, Aceh Selatan Regency", Skripsi, Universitas Syiahkuala.

Ilhartuti. (2013), "Feed species diversity of reintroduction Orangutan Jantho Reserve", Thesis, Universitas Sumatera Utara.

Giovana, D. (2015), "Daily activities and home range of Lutung Jawa (Trachypithecus auratus Raffles 1821) di Bama Resort, Baluran National Park", Thesis, Bogor IPB University.

Gurmaya, J,.K. (1986), "Eology and Behavior of Presbytis thomasi in Northern Sumatera”,. Primates j. 27 (2), $151-172$

Keys. R.C., Iskandar E., Kyes, P., \& Novak M.F.S.X. (2016). "Field Course in Consercation Biology \& Global Health: At te Human- Environment Interface"

Rahmawati, E., \& Hidayat, J.W. (2017),.’Population density of Lutung Jawa (Trachypithecus auratus) in Kecubung Reserve, Ulolanang, Batang Regency, Central Jawa. Proceeding Biology Education Conference, $14(1), 64-69$.

Roos, C., Boonratana, R, Supriatna, J,. Fellowes, J.R., Groves, C P,, Nash, S.D,. Rylands A.B., \& Mittermeir RA. (2014), “An uptudated taxonomy and conservation status review of asian primate".. As prim j, 4 (1), 338

Slater, H. (2015),"Forest structure and group density of Thomas' langur monkey, Presbytis thomasi, Thesis, Bournemouth University.

Syaukani. (2012), "Study of population and home range of Thomas Langur (Presbytis thomasi) at Soraya Research Station, Leuser Ecosystem”. Jurnal Natural. 12 (1), 37-41.

Sterck, E.H.M., Willems, E.P., Jan ARAM., van Hooff, \& Wich SA. (2005), "Female dispersal, inbreeding avoidance, and mate choice in Thomas langurs (Presbytis thomasi)". Journal Behaviour. 142 (7), 845-868.

Supriatna, J.,\& Hendras, E.W. (2000). “Field guide of Indonesia Primate”.Yayasan Obor Indonesia. Jakarta.

Steenbeek, R. (1999). "Femail Choice and Male Coercion in wild Thomas's langur. Vrouwelijke keuze en mannalijke dwang in wilde Thomas' Langoeren. Met een samenvatting in her Nederlans". PhD Thesis, Utrecht University.

Sterck, E.H.M. (1995), "Female, Food and Fights A sociological Comparison of the Sympatric Thomas Langur and Long Tailed Macaque, met een samenvatting in het Nederlands", PhD Thesis, Utrecht University.

Violita, C.Y., Setiawan, A, \& Rustiati. E.L. (2015), Group size of simpai (Presbytis melalophos) in Cugug Village forest, Forest Unit Management Gunung Raja Basa, Lampung Selatan. Journal Silva Lestari. 3 (3), 11-18.

van Schaik. C..P., S \& upriatna J, (1996) "Leuser A Sumatran Santuary". Yayasan Bina Sains Hayati Indonesia (YABSHI) PO. Box 103. Depok Indonesia.

Widiana, A, Hasbi, R.M., \& Uriawan, W. (2018). Distribution and population estimation of surili (Presbytis comata) in Kamojang, Garut Regency, West Jawa. Al-kauniyah: Journal of Biology. 11(2), 116-121.

Wich, S.A., Elisabeth, H.M., Sterck, S., Gursky-Doyen \& Supriatna, J. (2010). Chapter 17 Thomas Langurs: Ecology, Sexual Conflict and Social Dynamics dalam Indonesian Primates, Developments in Primatology: Progress and Prospects, Springer Science, Business Media, LLC.

Wich. S.A, Romy S, Sterch, E.H.M, Korstjens, A.H, Willems, E.P., \& van Shaick CP. (2007). Demography and life history of Thomas langur (Presbytis thomasi). American Journal of Primatology,. 6(9).641-651.

Wich, S.A. (2002). "The Structure and Function of Male Thomas Langur Loud Call. Met een samenvatting in her Nederlands. PhD Thtesis, Utrecht University.

Zannah, R. (2017), "Analisis vegetasi pohon di plot fenologi pos monitoring Sikundur Taman Nasional Gunung Leuser”, SkripsiI Sarjana. Universitas Medan Area.

\section{AUTHOR BIODATA}

1,6 Ruskhanidar, Born in Cot Jambo Aceh Besar, Aceh province, January 14, 1968. Completed his Bachelor's degree at the Pante Kulu Darussalam School of Forestry in Banda Aceh, Aceh Province, Indonesia in 1993 in the field of Forestry Resources Conservation and a master's degree in land resource conservation study program, Syiah Kula University. Darussalam Banda Aceh. Aceh Province, Indonesia in 2007, while the doctoral program at IPB University Bogor Indonesia in 2020, in the primatology study program. Scientific publications that have previously been published on the population and distribution of primate animals in the Indonesian Primate journal IPB, and the conservation of the thomas langur population in the Jantho Pine Nature Reserve in the journal of Conservation of Forest Conservation and Nature Conservation, Research and Development of the Indonesian Ministry of Forestry. works as a lecturer at the Forestry College Pante Kulu Darussalam Banda aceh.

1. Hadi Sukadi Alikodra, is a senior lecturer at IPB University in the field of forest resource conservation at the Faculty of Forestry of IPB University Indonesia, has produced many works in the form of books including Wildlife management techniques, published by IPB Press, Conservation of Natural Resources and the environment. which was published by Gadjah Mada University Press and Conservation Ecology 
Management of wild animals published by IPB press in 2019 and grounding Ecosophi in 2020.

2. Entang Iskandar, Date of birth 19 June 1967 in the of Java Barat Indonesia, Bachelor of Forest Resources Conservation, Faculty of Forestry, Bogor Agricultural University in 1992, Masters and Doctorates obtained from the primatology study program in 1998 and 2007 IPB University. The focus of publication is on primates.

3. Nyoto Santoso, senior lecturer at the forestry faculty, Bogor Agricultural University. In the study of the Tropical Biodiversity Conservation program. Active in various researches, and national and international meeting forums. The last three years of research include:

The impacts of oil palm plantation establishment on the habitat type, species diversity, and feeding guild of mammals and herpetofauna RTRI KWATRINA, Y SANTOSA, M Bismark, N SANTOSO Biodiversitas Journal of Biological Diversity

Ecological Impacts of Oil-Palm Plantation on Butterfly and Bird Species Diversity RT Kwatrina, Y Santosa, M Bismark, N Santoso Jurnal Manajemen Hutan Tropika

4. Sri Supraptini Mansjoer. IPB senior lecturer who works at the Faculty of Animal Husbandry of IPB University. has worked in various organizations and been involved in various activities 